\title{
Effectiveness of Pelvic Rocking and Gym Ball Exercise Against of Duration of Labor in the First Stage
}

\author{
$1^{\text {st }}$ Lestari Puji Astuti \\ Departement of Midwifery Karya \\ Husada Health Science Institute of \\ Semarang \\ Indonesia \\ tari.stikeskh@gmail.com \\ $4^{\text {th }}$ Saadah Mujahidah \\ Departement of Midwifery Karya \\ Husada Health Science Institute of \\ Semarang \\ Indonesia
}

\author{
$2^{\text {nd }}$ Puji Siswanti \\ Departement of Midwifery Karya \\ Husada Health Science Institute of \\ Semarang \\ Indonesia
}

\author{
$3^{\text {rd }}$ Durrotun Munafiah \\ Departement of Midwifery Karya \\ Husada Health Science Institute of \\ Semarang \\ Indonesia
}

\begin{abstract}
Childbirth is a process of expulsion from the conception (fetus and placenta) which is quite months or can live outside the womb through the birth canal or through other ways, using the assistance or without assistance (strength alone or spontaneous). Pelvic rocking can help the mother in an upright position, staying upright when in labor will allow the uterus to work as efficiently as possible by making the pelvic plane wider and open. Other physiological efforts besides moving pelvic rocking are gym ball exercises. A physical therapy ball that helps with labor and can be used in various positions. The purpose of this study was to determine the differences in the effectiveness of pelvic rocking and gym ball exercise for a long time $I$. This type of research is a quasi experiment using Post test only nonequivalent control group design, there were 30 respondent categoriezed into an intervention group $(n=15)$ pelvic rocking and birth ball exercise $(n=15)$. There is a difference in the effectiveness of pelvic rocking and gym ball exercise against the length of time I (P-value 0. 023). Pelvic rocking and gym ball exercise can accelerate the duration of labor in the first stage.
\end{abstract}

\section{Keywords-Pelvic Rocking, Gym Ball, Labor}

\section{INTRODUCTION}

Childbirth is the process of expulsion from the conception (fetus and placenta) which is of sufficient pregnancy age and can live outside the womb through the birth canal or other ways with the help or with the strength of the mother herself $[1,2]$. The incidence of old childbirth is still high according to the health profile of the Ministry of Health (MOH) in 2017, old parturition mothers who were hospitalized in hospitals in Indonesia obtained a proportion of $4.3 \%$ which is 12,176 of 281,050 births. The results of the Maternal Perinatal Audit (AMP) in Central
Java during the period of 2016 to 2017 found that the most difficult complication for mothers was old labor by $16 \%$. Research conducted in Yogyakarta found that out of 3005 cases of prolonged labor, 16.4\% (50 babies) of infants died, whereas in mothers there were 4 deaths. The Indonesian Health Demographic Survey (IDHS) in 2017 also noted that prolonged labor by $42.96 \%$ was the main cause of maternal and perinatal death followed by hemorrhage $35.26 \%$, and eclampsia $16.44 \%$ [3]. WHO data in 2017 states that the main complications that cause almost $75 \%$ of all maternal deaths are heavy bleeding (mostly bleeding after childbirth), infection (usually after giving birth), high blood pressure during pregnancy (preeclampsia and eclampsia), complications from labor unsafe abortion. The survey results found that prolonged parturition can cause emergencies in mothers and infants, in mothers bleeding and shock can occur, in infants can occur fetal distress, asphyxia, and headache. This illustrates the importance of assistance with skilled health workers because most of the complications occur during delivery[4].

One of the objectives of the Sustainable development goals (SDGs) is committed to reducing the maternal mortality rate (MMR) with a target of reducing maternal mortality by 70 per 100,000 live births in the period 2015 - 2030. Several attempts have been made by the government to reduce maternal mortality, including help deliveries by health workers to $85 \%$, early detection, antenatal care, good management of childbirth and childbirth $[4,5]$.

Various physiological efforts were made to prevent prolonged labor, such as pregnancy exercise, deep 
breathing techniques, birthing ball exercise and pelvic rocking [6]. Pelvic rocking can help the mother in an upright position, staying upright when in labor will allow the uterus to work as efficiently as possible by making the pelvic plane wider and open. In other words, it can stimulate dilatation and widen the pelvic outlet. Sitting straight will create an earth's gravitational force which will help the fetus or the lowest part of the fetus to descend immediately to the pelvis so that shorter or shorter labor times are obtained [7]. Pelvic rocking is a movement of pelvic rocking forward, backward, and rotation to the left and right, with the aim of accelerating the progress of labor, reducing pain, helping decrease the baby's head with the help of gravity $[1,7,8]$.

Gym ball exercises help to open the pelvis wider, helping to relieve pain during labor, reduce pain during contractions, relieve anxiety and stress during labor and the time of delivery will be much shorter, especially if you have routinely done gym ball exercises a few months before the process labor.[9]

\section{METHOD}

This research is quasi-experimental (posttest only with control group design). Performed at the Community Health Center (Puskesmas). The sampling technique used was accidental sampling involving 30 respondents. Respondents were categorized into two groups, namely intervention $(n=15)$ given pelvic rocking, $(n=15)$ given gym ball exercise. The intervention was carried out during the first stage of labor starting from the opening of 4-10 $\mathrm{cm}$.
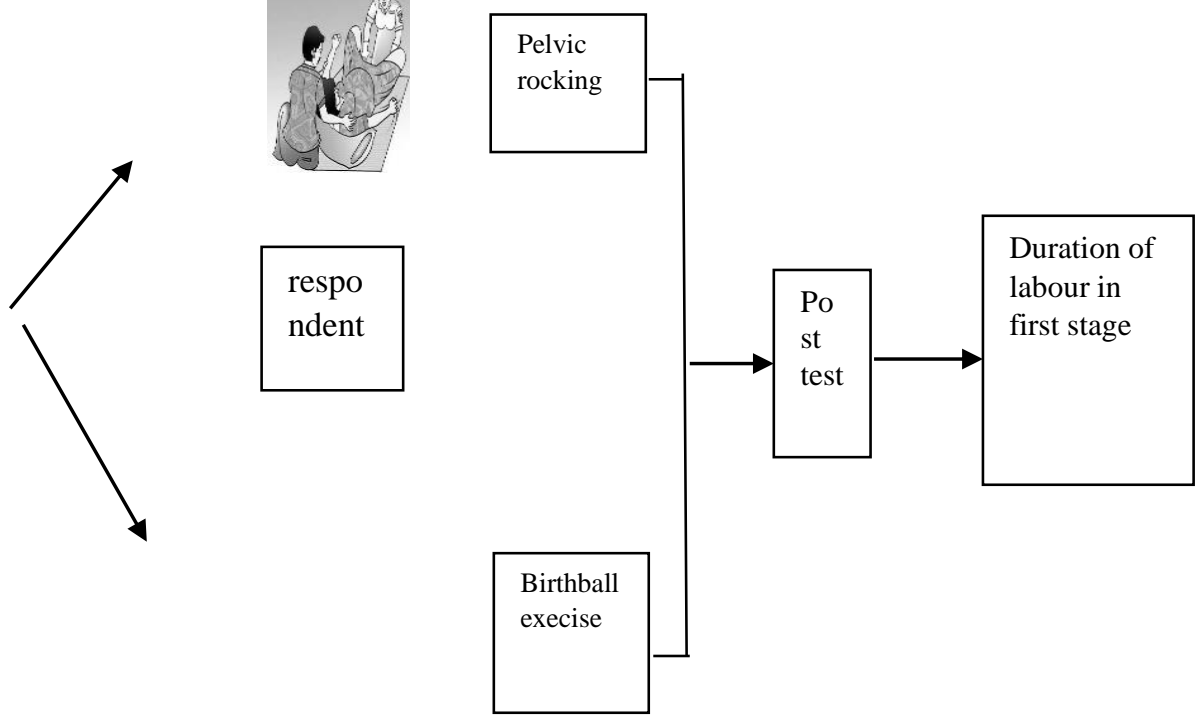

Fig. 1. Flowchart

\section{RESULT AND DISCUSSION}

The research respondents were first-time active mothers starting from opening $4-10 \mathrm{~cm}$. While the data collected is derived from identity data and observations of labor. Informed consent was immediately made to the respondent by explaining the procedure and benefits of the study.

\section{A. Characteristics of Respondent}

This study shows that the majority of responden have the age $20-35$ year $(83.33 \%)$ and education in Senior High $(56.67 \%)$. As presented in Table II.

TABLE I. CHARACTERISTICS OF RESPONDENTS

\begin{tabular}{|c|r|r|}
\hline Characteristics of respondent & Frequency & Percent $(\%)$ \\
\hline Age $\quad$ & 25 & \\
\hline Age 20-35 & 5 & 83.33 \\
\hline Age >35 & & 16.67 \\
\hline Education & 7 & \\
\hline Junior High & 17 & 23.33 \\
\hline Senior High & 2 & 56.67 \\
\hline Diploma & 3 & 6.67 \\
\hline Bachelor & 1 & 10.0 \\
\hline Post Graduated & & 3.33 \\
\hline
\end{tabular}

\section{B. Statistical Analysis}

Table II shows that there was a decrease in the average delivery time in the pelvic rocking group by 5.47 and in the birth ball exercise group by 4.53 . 
TABLE 2. EFFECTIVENESS OF PELVIC ROCKING AND GYM BALL EXERCISE AGAINST OF DURATION OF LABOR IN THE FIRST STAGE

\begin{tabular}{|r|r|r|c|c|c|}
\hline Group & $\mathbf{n}$ & $\boldsymbol{\%}$ & Mean & SD & p-value \\
\hline Pelvic Rocking & 15 & 50 & 5.47 & 1.060 & \multirow{2}{*}{0.023} \\
\hline Birthball exercise & 15 & 50 & 4.53 & 1.060 & \\
\hline
\end{tabular}

In the independent T-test, p-value $(0.023)<0.05$ can be concluded that there is a statistically significant difference between the pelvic rocking intervention group and birth ball exercise on the duration of the first stage of labor.

Prolonged labor is one of the causes of increased maternal and fetal mortality and morbidity. Mothers with prolonged labor are more at risk of bleeding due to uterine atony, laceration of the birth canal, infection, fatigue and shock, whereas in the fetus can increase the risk of severe asphyxia, cerebral trauma, infection and injury from the action [10]. Interventions that are often carried out include oxytocin induction, vacuum extraction, and cesarean section and we can be sure these interventions increase maternal and infant morbidity $[1,2,8,9]$.

Mobility training from the mother is needed to keep the ligaments loose, relaxed, free of tension and more room for the baby to get down the pelvis so that the length of the first and second stages of labor can be shortened by doing exercises/body work [11,12]. Movement on the Pelvic Rocking by shaking the pelvis to the front, back, left and right sides can train the muscles of the waist, hips and help lower the baby's head to enter the pelvic cavity toward the road. Therefore Pelvic Rocking is necessary for mothers to give birth to reduce pain during labor and improve the quality of life of mothers and their babies [13]. Pelvic Rocking and Gym Ball is to increase the size of the pelvic cavity by rocking the pelvis with the ball and slowly swinging the hips forward and back, right side, left, and circular. In other words, it can stimulate dilatation and widen the pelvic outlet. Sitting straight on the ball, the earth's gravity will help the fetus or the lowest part of the fetus to descend immediately to the pelvis so that the delivery time is shorter or shorter [14-17].

\section{CONCLUSION}

This study showed that pelvic rocking and birthball exercise can reduce the duration of labour in the first stage. The result of this study can be useful in the planning of birth programs so the patients can lamafeel relaxing and comfortable for labour.

\section{ACKNOWLEDGMENTS}

For further researchers, it is expected to be able to make literature and examine research methods and other variables that affect the duration of labor at stage I.

\section{REFERENCES}

[1] Astuti HP. Buku Ajar Asuhan Kebidanan Ibu I (Kehamilan). Rohima Pres, Yogyakarta. 2012;268.

[2] Sondakh J. Asuhan Kebidanan Persalinan dan Bayi Baru Lahir. Jakarta: Erlangga. 2013.

[3] Indonesia KR. Profil kesehatan Indonesia tahun 2017. 2017.

[4] Organization. WH. Maternal mortality: World Health Organization. ; 2017 [Available from: https://www.who.int/en/news-room/fact-sheets/detail/maternalmortality.

[5] Saifuddin AB. Buku acuan nasional pelayanan kesehatan maternal dan neonatal. Jakarta: Yayasan Bina Pustaka Sarwono Prawirohardjo. 2010;100:111-2.

[6] Ratnasari NN, Pertiwi S, Khairiyah II. Pengaruh Pelvic Rocking Exercise terhadap Nyeri Primary Dysmenorhea pada Siswi Kelas VIII. Jurnal Bidan. 2018;4(2):267041.

[7] Aprilia Y. Gentle Birth Balance: persalinan holistik mind, body and soul. Bandung: Mizan Pustaka, hal. 2014:20-35.

[8] Sofian A, editor Rustam Mochtar Sinopsis Obstetri: Obstetri Operatif, Obstetri Sosial2013: EGC.

[9] Manuba IBG, editor Ilmu Kebidanan, penyakit kandungan dan keluarga berencana untuk pendidikan bidan2009: EGC.

[10] Oxorn H, Forte WR. Ilmu kebidanan: patologi dan fisiologi persalinan: Penerbit Andi; 2010.

[11] Surtiningsih S. Efektifitas Pelvic Rocking Exercises terhadap Lama Waktu Persalinan pada Ibu Primipara di Puskesmas Wilayah Kabupaten Banjarnegara. Jurnal Keperawatan Soedirman. 2018;11(2):117-29.

[12] Susiloretni KA, Wahyuni S. Efektivitas Pelvic Rocking Exercises terhadap Lama Waktu Persalinan pada Ibu Primipara. Jurnal Ilmiah Kesehatan (JIK). 2017;10(2).

[13] Gustyar I. Penerapan Teknik Pelvic Rocking dengan Birthing Ball Pada Ibu Bersalin Terhadap Kemajuan Persalinan di Bpm Syafrida Kabupaten Kebumen Tahun 2017: Stikes Muhammadiyah Gombong; 2017.

[14] Nayak S. A Comparative Study On Effect Of Ambulation And Birthing Ball On Maternal And Newborn Outcome Among Primigravida Mothers In Selected Hospitals In Mangalore.

[15] Sarah Beake R, Associate R, Chang Y-S, Helen Cheyne R, Spiby H, RM JS, et al. Experiences of early labour management from perspectives of women, labour companions and health professionals: A systematic review of qualitative evidence. Midwifery. 2018;57:69-84.

[16] Sriwenda D, Yulinda Y. Efektifitas Latihan Birth Ball Terhadap Efikasi Diri Primipara dengan Persalinan Normal. Jurnal Ners dan Kebidanan Indonesia. 2017;4(3):141-7.

[17] Gau M-L, Chang C-Y, Tian S-H, Lin K-C. Effects of birth ball exercise on pain and self-efficacy during childbirth: $a$ randomised controlled trial in Taiwan. Midwifery. 2011;27(6):e293-e300. 